\title{
Australian Alleculinae: New Genera, New Combinations, and a Lectotype Designation (Coleoptera: Tenebrionidae)
}

\author{
Eric G. Matthews \\ South Australian Museum, North Terrace, Adelaide, SA 5000, Australia \\ Correspondence should be addressed to Eric G. Matthews, eric.matthews@samuseum.sa.gov.au \\ Received 15 September 2011; Revised 29 November 2011; Accepted 9 December 2011 \\ Academic Editor: Donald Mullins
}

Copyright () 2012 Eric G. Matthews. This is an open access article distributed under the Creative Commons Attribution License, which permits unrestricted use, distribution, and reproduction in any medium, provided the original work is properly cited.

Litopous baehri gen. et sp. nov. and Scaphinion clavatus gen. et sp. nov. are described. New combinations (previous genus in parentheses) are Aethyssius minor (Carter) (Tanychilus Newman), Homotrysis subopaca (Carter) (Metistete Pascoe), Metistete armata Carter (Homotrysis Pascoe), M. opaca (Carter) (Tanychilus), M. punctata (Carter) (Melaps Carter), and Nocar subfasciatus Carter (Taxes Champion). A lectotype and two paralectotypes are designated for Dimorphochilus diversicollis Borchmann which is removed from synonymy, and the genus is briefly discussed.

\section{Introduction}

Australian Alleculinae are poorly known and there are numerous unnamed species. Many species that are now included in genera such as Homotrysis Pascoe, Metistete Pascoe, and Aethyssius Pascoe apparently belong to other genera, but no consistently reliable morphological characters have been proposed to distinguish them. In the present paper two such taxa from Western Australia are included in two new genera based on the discovery of diagnostic characters. Another taxon from the same state was considered as possibly belonging to a third distinct genus with simple tarsal claws, a character very unusual in the Alleculinae. However, examination of the claws under high magnification revealed that the inner edges are minutely crenulated, and also in other respects, such as the apically unidentate mandibles, cultriform terminal maxillary palpomere and front of head not produced, this species (unnamed) falls within the current concept of Aethyssius.

The terms frontal index and stomatiform punctures follow Matthews and Bouchard [1], and the checklist of names included in that work gives the dates and citations of all descriptions.

\section{Material}

Material from the following collections was examined:

\begin{abstract}
AM: Australian Museum, Sydney;
ANIC: Australian National Insect Collection, Canberra;

ANIC(MM): Macleay Museum material on permanent loan to ANIC;

BMNH: Natural History Museum, London;

NMV: Museum of Victoria, Melbourne;

QM: Queensland Museum, South Brisbane;

SAMA: South Australian Museum, Adelaide;

WAMA: Western Australian Museum, Perth;

ZSM: Zoologische Staatssammlung, Munich.
\end{abstract}

\section{New Genera}

\subsection{Litopous gen. nov.}

Type Species. Litopous baehri sp. nov.

Description. Oblong, densely setose with long erect bristles on all dorsal surfaces and legs. Head not prolonged. Antennomeres elongate, bearing dense long bristles, only a few compound sensoria on apical 3 segments. Eyes deeply emarginate anteriorly. Mandibles bluntly bidentate. Apical maxillary palpomere roundedly securiform, symmetrical. 
Tarsi bearing long bristles only, without lobes or cupuliform segments. Claws not pectinate, with only small teeth on basal half of inner edges (Figure $2(\mathrm{~d})$ ) . Intercoxal process of first ventrite acutely angular. Length $8.3 \mathrm{~mm}$.

Distribution (Figure 3). Known only from the type locality near Wurarga inland from Geraldton, WA.

Etymology. Greek litos $=$ plain, pous $=$ foot.

Discussion. This is the most unusual Australian alleculine examined, having no trace of lobes or cupuliform tarsomeres. The penultimate segment of the protarsus bears two stout diverging acute projections, probably coalesced bristles. The teeth on the tarsal claws are very short (Figure 2(d)), not typically pectinate as in all other known Australian Alleculinae except the unrelated Hemicistela Blackburn and the simple-clawed species mentioned in the introduction. The antennae are also unusual in bearing numerous long stiff setae and very few compound sensoria. According to current classifications of the subfamily (e.g., Matthews et al. [2]) Litopous does not fit into the subtribe Alleculina as other Australian alleculines because of the absence of tarsal lobes, and it does not conform to the diagnostic characters of any of the other higher taxa of the subfamily as discussed by Campbell [3]. For the present, this genus will be treated as incertae sedis within the tribe Alleculini.

\subsection{Litopous baehri sp. nov. (Figures 1(a), 2(d), 3)}

Description of Female. Elongate-oblong, uniformly dark brunneous, with dense erect setae, total length $8.3 \mathrm{~mm}$, width at humeri $2.7 \mathrm{~mm}$.

Head. Frons and clypeus not prolonged, frontal index 0.42, edges indented at frontoclypeal suture, which is impressed. Basal membrane of labrum short, labrum very transverse bearing long stiff bristles. Eyes moderate, separate dorsally by distance equal to a little more than width of one eye. Antennomere 3 longer than 4 but shorter than $4+5$, segments gradually shortening distad, terminal segment fusiform and apically acute. Antennomeres $1-7$ bearing long bristles, $8-11$ short stout setae, only a few compound sensoria on apical 3 segments. Mandibles short, bluntly bidentate.

Prothorax. Subquadrate, 1.2 times as wide as long, sides strongly convex, maximum width a little before middle. Pronotal surface densely and coarsely punctuate, punctures bearing long erect bristles. Prosternal process about as wide as half of one procoxa.

Pterothorax. Much wider than prothorax, sides of elytra straight, subparallel for anterior $2 / 3$, roundedly tapering posteriorly. Striae deeply impressed, strial punctures round, simple, separated by distance about equal to one-puncture diameter. Interstriae with numerous punctures bearing long erect bristles. Wings fully developed.

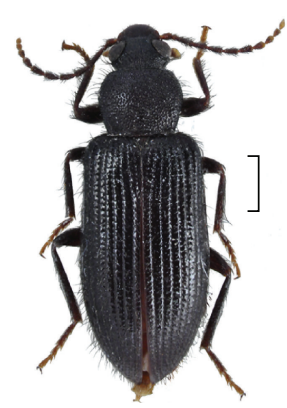

(a)

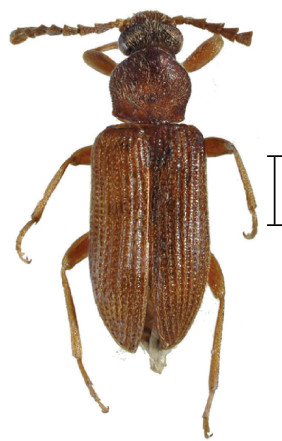

(b)

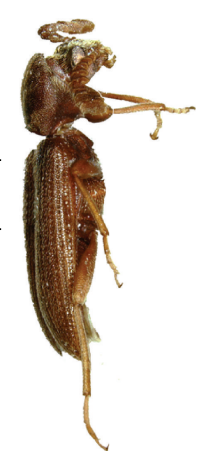

(c)
FIgURE 1: Habitus. (a) Litopous baehri sp. nov. female; (b) Scaphinion clavatus sp. nov. male, dorsal; (c) ditto, lateral. Scale lines $1 \mathrm{~mm}$.

Legs. Slender, unmodified, femora projecting beyond body outline for about half their length. Tarsi a little longer than half tibial length, basal metatarsomere a little longer than next 3 combined.

Abdomen. Intercoxal process of first ventrite acutely triangular.

Male. Unknown.

Type. Holotype female: Australia, WA 06/168, $2 \mathrm{~km}$ SE Wurarga, 28.37913 S, 116.33105 E, $371 \mathrm{~m}, 3-4.3 .2006$, M. Baehr. WAMA Reg. no. 82708.

Etymology. The author takes pleasure in naming this species after its collector, Martin Baehr of ZSM.

\subsection{Scaphinion gen. nov.}

Type Species. Scaphinion clavatus sp. nov.

Description. Elongate-oblong, bearing long recumbent setae. Head not prolonged. Eyes large, deeply emarginate. Antennomeres sometimes greatly enlarged distally. Mandibles small, acutely bidentate. Apical maxillary palpomere broadly securiform, somewhat asymmetrical. Occiput deeply transversely excavate and receiving prolongation of anterior part of pronotal disc. Elytral punctures uniformly large, deep, with sides thickened (stomatiform). Tarsi with small square lobes on penultimate segments. Claws pectinate. Total length $\pm 5 \mathrm{~mm}$ (based on 3 available specimens of the genus).

Distribution (Figure 3). The Kimberley District of northwestern Australia where all three known species were collected.

Etymology. Greek scaphe $=$ hollowed out, inion $=$ back of head.

Discussion. Scaphinion is related to Metistete Pascoe because the elytral punctures are entirely stomatiform. All three 


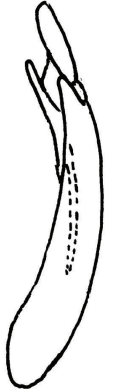

(a)

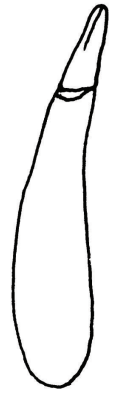

(b)

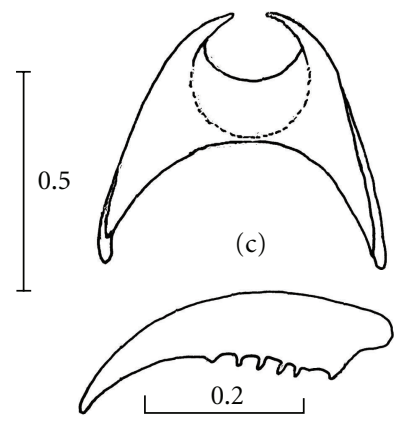

(d)
Figure 2: Outlines. (a) Scaphinion clavatus aedeagus, lateral; (b) ditto, dorsal; (c) S. clavatus sternite 8; (d) Litopous baehri, tarsal claw.

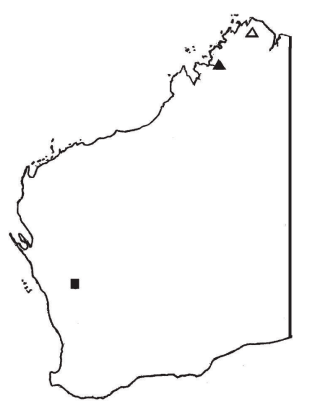

Figure 3: Known distributions in Western Australia. (ם) Litopous

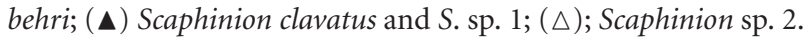

known species differ from the latter genus in having the pronotum anteriorly prolonged and received in a concavity of the occiput. The enlargement of the antennae of two of the known specimens (Figures 4(a), 4(b)) is also unknown in Metistete. The third specimen has simple antennae (Figure $4(\mathrm{c})$ ). The three male specimens known of this genus each belong to a different species as discussed below. The author believes that in general it is not desirable to describe new species of known genera on the basis of single specimens, but where new genera are clearly involved, as is the case in the present paper, they should be described even though their type species are initially represented by uniques. The two species of Scaphinion which are not types of the genus are briefly characterized but not named now in order to illustrate some of the specific diversity which is to be expected in the genus. A forthcoming faunal survey of the Kimberley District by the Western Australian Department of Environment and Conservation should discover more specimens of the genus and thus permit detailed descriptions of both sexes.

\subsection{Scaphinion clavatus sp. nov. (Figures 1(b), 1(c), 2(a), 2(b), $2(c), 3$, and $4(a))$}

Description of Male. Elongate oblong, uniformly fuscous, with dense recumbent setae, total length $5.3 \mathrm{~mm}$, width at humeri $1.8 \mathrm{~mm}$.
Head. Clypeus broadly truncate, sides diverging and forming a straight line with edges of canthi. Head moderately prolonged, frontal index 1.0. Basal membrane of labrum very short, labrum very transverse, bearing moderately long setae. Eyes deeply emarginate anteriorly, large, separated by a distance subequal to about 1.5 eye width as seen from above. Antennomere 3 about as long as 4, 3-9 subtriangular, gradually widening and becoming asymmetrical, 10 very transverse, wider than 9, 11 transverse, smaller than 10 and contained within a cavity of latter (Figure 4(a)). All segments bearing short setae, 3-11 with numerous compound sensoria. Mandibles small, acutely bidentate.

Prothorax. Anterior edge of pronotum strongly produced to broadly rounded apex which overhangs base of head, pronotum widest just behind middle, sides slightly convergent to base, basal edge straight. Ratio of maximum width to length $1: 1$. Pronotal surface densely and coarsely punctate with long recumbent setae. Prosternal process as wide between coxae as $1 / 3$ width of 1 coxa.

Pterothorax. Much wider than prothorax, sides of elytra subparallel for anterior $2 / 3$, broadly tapering to apices. Striae not impressed, consisting of very large and deep, close-set rounded stomatiform punctures. Interstriae with numerous small punctures bearing long recumbent setae. Wings fully developed.

Legs. Moderately slender and setose, femora with about $1 / 2$ of their length projecting beyond elytral edges. Tibiae subparallel, slightly bowed, not distorted. Tarsi about $1 / 3$ length of tibiae. Lobes of preapical tarsomeres small.

Abdomen. Intercoxal process of first ventrite acutely triangular. Aedeagus (Figures 2(a) and 2(b)) simple.

Female. Unknown.

Type. Holotype male. 16.22S 125.12E W.A. Charnley Riv. $2 \mathrm{~km}$ SW Rolly Hill CALM site 25/2 16-20 June 1988, I.D. Naumann, at light, open forest near closed forest margin, ANIC.

Discussion. The three known male specimens belong to three different species, S. clavatus and two others which remain unnamed for now for the reasons discussed above. The latter two have the following locality data: Species 1, 16.38S 125.15E CALM site $28 / 34 \mathrm{~km}$ W of King Cascade, W.A., 12-16 June 1988 T.A. Weir, at light closed forest margin, ANIC; species 2, 14.39S 126.57E Drysdale River, W.A. 1821 Aug. 1975, I.F.B. Common and M.S. Upton, ANIC. The most obvious difference between the three is in the form of the antennae, sp. 1 having only moderately enlarged antennae (Figure 4(b)) and sp. 2 unmodified filiform ones (Figure 4(c)). In addition, in both unnamed species the eyes are larger than in clavatus, the interocular distance being equal to about half an eye width and the shape of abdominal sternite 8 is different in all three species, this being the most 


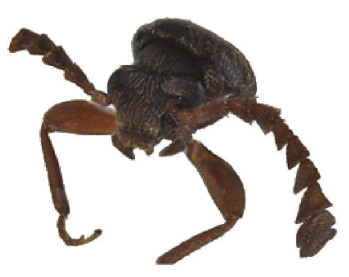

(a)

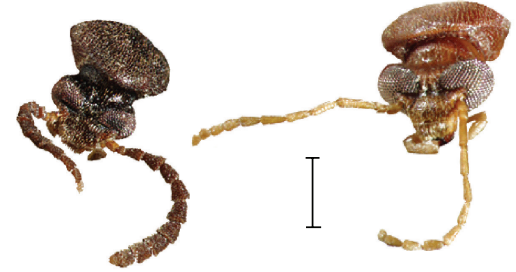

(b) (c)

Figure 4: Head and prothorax of Scaphinion. (a) S. clavatus; (b) S. sp. 1; (c) S. sp. 2. Scale line $1 \mathrm{~mm}$ for all figures.

reliable indication of specific distinctness. The aedeagi are identical.

\section{New Combinations}

A recent examination of Carter types of Alleculinae in NMV revealed that a number of species were incorrectly assigned to genus in [1]. The following names are transferred to different genera from those listed in the latter work. The correct generic name is first and the name in [1] is in parentheses.

\section{Aethyssius minor (Carter) (Tanychilus Newman). \\ Homotrysis subopaca (Carter) (Metistete Pascoe). \\ Metistete armata Carter (Homotrysis Pascoe). Carter placed this species in the correct genus but it was wrongly assigned by [1]. \\ Metistete opaca (Carter) (Tanychilus). \\ Metistete punctata (Carter) (Melaps Carter). \\ Nocar subfasciatus Carter (Taxes Champion). Also placed correctly by Carter but misplaced by [1]}

\section{Previous Lectotype Designations}

Carter and other authors of that time did not specifically designate holotypes in their descriptions, but they always labelled one specimen of the type series as the "Type" and the others as cotypes, clearly intending that they should be considered holotype and paratypes, respectively. In all unpublished museum catalogs and lists, the specimens which bear the label "Type" are listed as holotypes and often given numbers. However, according to Article 74 of the ICZN [4] this is not sufficient for the specimens in question to be considered primary types unless they were clearly identified (or indicated to be unique) in the original descriptions. On the other hand, many Carter and Macleay numbered specimens are listed in print as holotypes in AM by McKeown [5] and in this case this action is tantamount to lectotype designation according to Article 74.6 of [4]. The names involved, listed in their present genera, are Aethyssius cyaneus (Macleay), A. cylindricollis (Carter), A. major (Carter), A. mastersi (Macleay), A. metallica (Carter), A. oculatus (Carter), A. piceus (Macleay), A. puncticeps (Blackburn), A. ruficollis (Macleay), A. rugosulus (Macleay), A. suturalis (Carter), A. tenuicornis (Carter), A. vitticollis (Macleay), Dimorphochilus pascoei (Macleay), Euomma palpalis (Macleay), E. mastersi
(Macleay), Homotrysis albolineata Carter, H. interstitialis Carter, H. mastersi (Macleay), H. montium Carter, H. ruficornis Macleay, $H$. rufobrunnea Carter, $H$. sexualis Carter, $H$. silvestris Carter, H. subgeminata Macleay, Metistete clermontia (Carter), M. elongata (Macleay), M. illidgei (Carter), $M$. pascoei (Macleay), M. planicollis (Macleay), M. punctipennis (Macleay), M. rufipilis (Carter), M. subsulcata (Macleay), M. yeppoonensis (Carter), Nocar convexus (Macleay), N. depressiusculus (Macleay), N. suttoni Carter, Ommatophorus mastersi Macleay, and Scaletomerus politus (Macleay). For all of these, "ST" in the checklist of [1] should be changed to LT.

The remaining approximately 80 specimens listed as holotypes or the equivalent in the catalogs of $\operatorname{ANIC}(\mathrm{MM})$, BMNH, NMV, QM, SAMA, and ZSM must be considered only syntypes unless the original descriptions were based on single specimens. In the checklist of [1] they are appropriately listed as ST and HT, respectively. In most cases the specimens labelled "Type" by their original describers will eventually be selected as lectotypes, but this action should be deferred until the taxa in question are revised.

5.1. Dimorphochilus Borchmann, 1908. Borchmann [6] described this as a new genus with three new species, $D$. apicalis, $D$. diversicollis, and $D$. sobrinus, collected during the Hamburg Museum Southwest Australia expedition of 1905. The concept of this genus was uncertain because $D$. sobrinus should be assigned to Tanychilus, which has apically unidentate mandibles unlike Dimorphochilus. Tanychilus gouldi (Hope) was also misplaced in Dimorphochilus by Carter [7] partly for this reason. The fixation of the type species of Dimorphochilus as D. apicalis Borchmann by [1] restricts the diagnostic characters of the genus as follows: apices of mandibles bidentate, or bilobate with a longitudinal groove between lobes; dorsal surfaces entirely glabrous, the body castaneous with legs paler, often flavous; elytra with simple punctures only and a sutural gap. The latter term refers to a widening of the suture at the apices of the elytra, the space thus opened being covered with overlapping expansions of the marginal membranes of the suture. This character is illustrated for D. apicalis by [1] in Figure $80 \mathrm{~K}$, which shows the extremely widened gap of a female on the right and the more normal one of a male on the left. Carter [8] erroneously synonymised $D$. diversicollis with $D$. apicalis. The former species is here resurrected following examination of the types listed below. 
The genus Dimorphochilus as now understood includes the following five named species known from the states indicated in parentheses: apicalis (WA), diversicollis (WA), caudatus (Carter) (Qld), luctuosus (Champion) (Tas), and pascoei (Macleay) (Qld, NSW). In addition, there are two unnamed species in SA, probably others elsewhere. There is some doubt about $D$. luctuosus as it is entirely piceous and the elytral gap is minimal.

The material collected during the Hamburg Southwest Australia expedition of 1905 was largely taken to Hamburg and subsequently destroyed during World War II. It was considered that Borchmann material of Alleculinae was likewise destroyed until three female specimens of $D$. diversicollis agreeing with the original description and bearing the expedition labels were discovered among miscellaneous accessions in WAMA. Borchmann had five males and numerous females of the species but did not designate a holotype. The specimens discovered are here designated lectotypes of Dimorphocilus diversicollis Borchmann, 1908 as follows, with the sequence of labels indicated by numbers in parentheses.

Lectotype Female. (1) (printed) Hamb. S. W. Austr. Exped. 1905. Stat. 76 Day Dawn 9.-10. VII; (2) (handwritten) Dimorphochilus diversicollis Borch. Cotype! 4238; (3) (yellow, printed) Western Australian Museum Entomology Reg no 57620; (4) (red, handwritten by author) LECTOTYPE Female Dimorphochilus diversicollis Borch. Sel. by E. Matthews.

Paralectotype Females (Two). (I) (1) as above Stat. 71 Northampton 4238a 15. VII; (2) as in 3 above Reg no. 57621; (3) (blue, handwritten by author) PARALECTOTYPE Female Dimorphochilus diversicollis Borch. (II) (1) as above Stat. 77 Yalgoo 4238b 11. VII. Dimorphochilus diversicollis originally handwritten on underside; (2) as in 3 above Reg no. 57622; (3) as in 3 for previous paralectotype.

\section{Acknowledgments}

The author wishes to thank the curators of the collections examined: Dave Britton (AM), Tom Weir (ANIC), Ken Walker (NMV), Max Barclay (BMNH), Geoff Thompson and Geoff Monteith (QM), Brian Hanich and Terry Houston (WAMA), Martin Baehr (ZSM), and also Roland Grimm for sending the specimen of Litopous baehri and Martin Baehr for donating it to WAMA.

\section{References}

[1] E. G. Matthews and P. Bouchard, Tenebrionid Beetles of Australia: Descriptions of Tribes, Keys to Genera, Catalogue of Species, Australian Biological Resources Study, Canberra, Australia, 2008.

[2] E. G. Matthews, J. F. Lawrence, P. Bouchard, W. E. Steiner Jr., and S. A. Slipinski, "Family Tenebrionidae," in Handbook of Zoology, A Natural History of the Phyla of the Animal Kingdom, R. G. Beutel and R. A. B. Leschen, Eds., vol. 4, pp. 574-659, Walter de Gruyter, Berlin, Germany, 2010, Arthropoda: Insecta, part 38, Coleoptera, Beetles, vol. 2, Systematics, part 2.
[3] J. M. Campbell, A Revision of the Genus Lobopoda (Coleoptera: Alleculidae) in North America and the West Indies, vol. 37 of Illinois Biological Monographs, University of Illinois Press, Urbana, Ill, USA, 1966.

[4] International Commission of Zoological Nomenclature, International Code of Zoological Nomenclature (ICZN), International Trust for Zoological Nomenclature, 4th edition, 1999.

[5] K. C. McKeown, "A reference list of types of Coleoptera in the Australian Museum," Records of the Australian Museum, vol. 22, no. 1, pp. 95-139, 1948.

[6] F. Borchmann, "Alleculidae," Die Fauna Südwest-Australiens, vol. 1, pp. 348-358, 1908.

[7] H. J. Carter, "Revisional notes on the family Cistelidae (Order Coleoptera)," Transactions of the Royal Society of South Australia, vol. 44, pp. 198-217, 1920.

[8] H. J. Carter, "Check list of the Australian Cistelidae. Order Coleoptera," Australian Zoologist, vol. 6, pp. 269-276, 1930. 

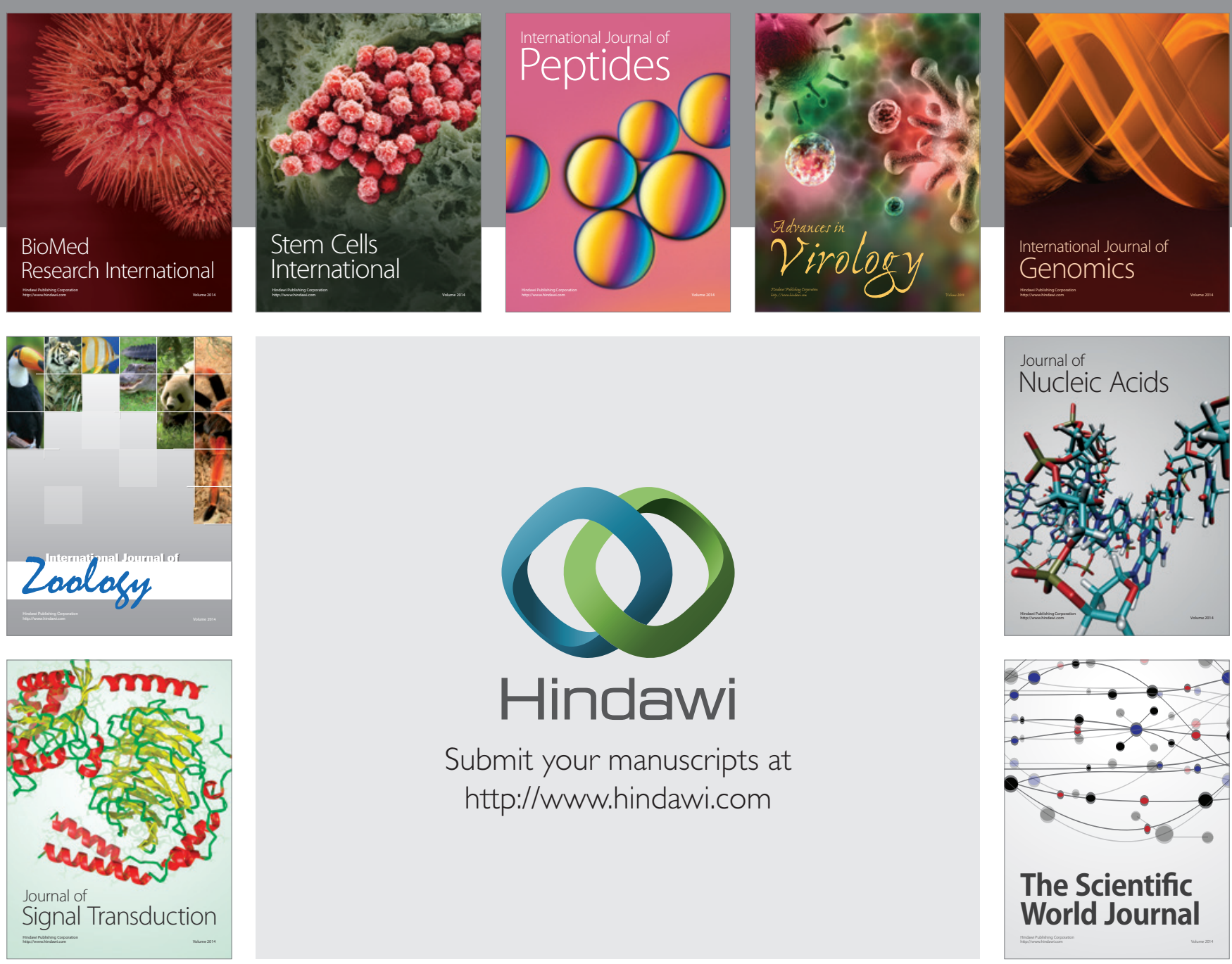

Submit your manuscripts at

http://www.hindawi.com
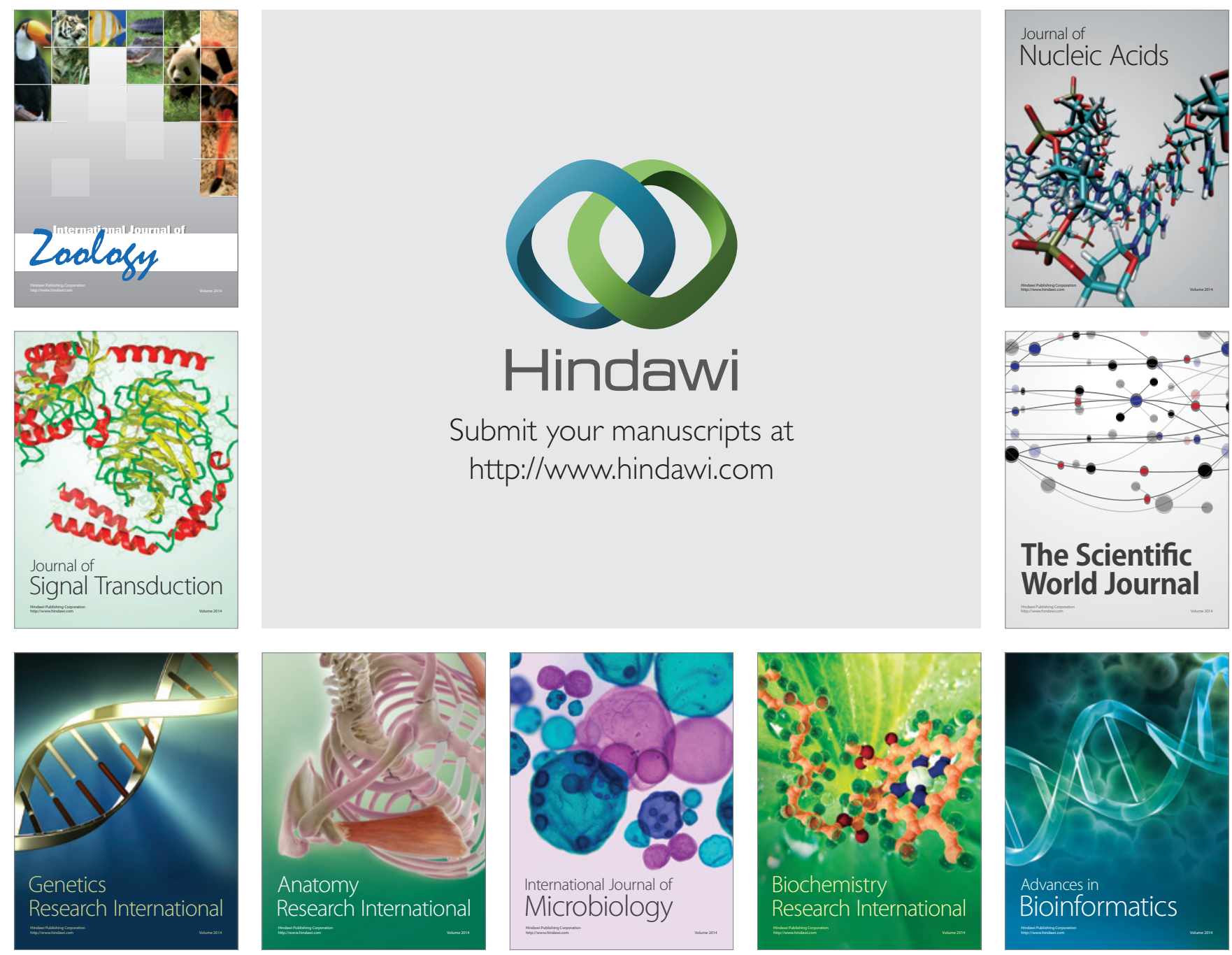

The Scientific World Journal
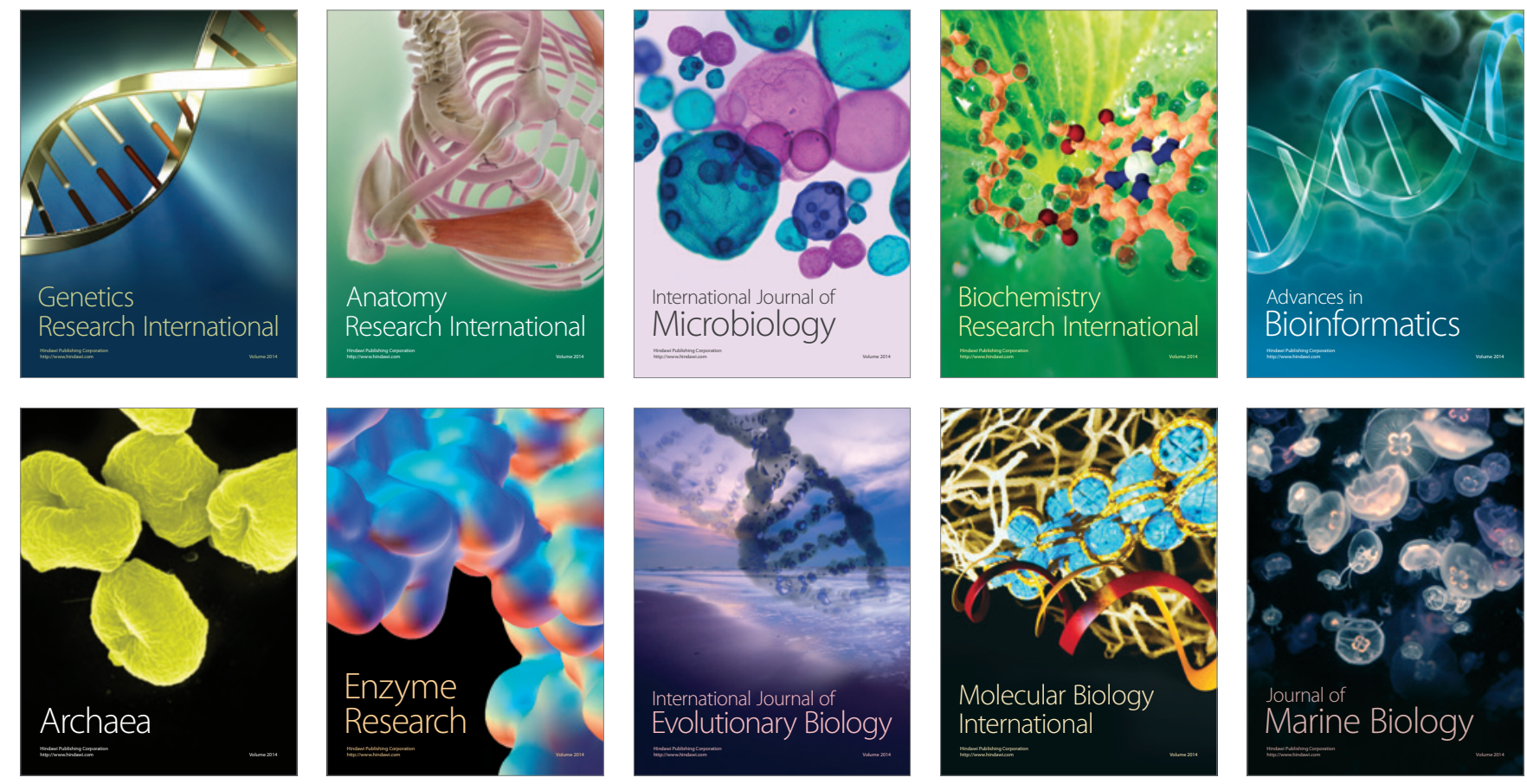